\title{
Foreign Language Education in Primary Schools in the People's Republic of China
}

\author{
Minglin Li \\ School of Education, The University of Queensland, St Lucia, Brisbane, \\ QLD 4072, Australia; and School of Foreign Languages, Ludong \\ University, Yantai, Shandong 264025, People's Republic of China
}

This paper analyses the national policies on foreign language in primary schools in the People's Republic of China (PRC). It begins with a brief introduction to the changes in foreign language education policy and the main motives for those changes in the context of socio-political circumstances. It then examines foreign language education in primary schools (FLPS) at different times in terms of aspects of language choice, curriculum design and materials development. The study shows that FLPS in the PRC has not been planned systematically but has developed in line with the changing socio-political situation, that is it has been determined to a large extent by political, economic and educational motives.

doi: $10.2167 /$ cilp113.0

Keywords: curriculum design, foreign language education, language choice, material development, policy change motives, primary schools

\section{Introduction}

Until recently, foreign language education in primary schools (FLPS) in the People's Republic of China (PRC) has not been planned systematically at the national level; policies have changed with the various shifts in the sociopolitical situation in general and with the different emphases in foreign language education in particular. As foreign language study is one of the categories of language the education sector deals with as part of the language-in-education planning process (Kaplan \& Baldauf, 1997), the study of foreign language education in primary schools in the PRC is to be situated in the context of language-in-education policy and planning.

Language-in-education planning, one of the three types of language planning (Cooper, 1989), focuses on the conceptualisation of the interrelationship between language policy-making and the classroom and its curriculum, and deals with the objectives of who will teach what language to whom, for how long, through what methodologies, with what materials, and finally with an examination of the extent to which such goals have been achieved (Grabe \& Kaplan, 1992; Ingram, 1989; Kaplan, 1990; Spolsky \& Shohamy, 2000). Generally speaking, the educational structures of the government make language policy decisions on political or economic grounds which are implemented through education sectors (Kaplan, 1990). Foreign language policy development in the PRC has 
followed this same top-down pattern. The government has decided what foreign language(s) is(are) to be useful, politically and economically, for the development of the nation. The Ministry of Education (MOE) creates policy and organises planning by issuing policy-related documents and developing activities related to policy implementation, by designing and issuing curricula, and by approving a list of textbooks from which to select teaching materials.

Researchers agree that intervening variables, such as economic, social, political and educational considerations, exist in the language planning process (e.g. Baldauf, 1990; Cooper, 1989; Rubin \& Jernudd, 1971). Judd (1992) suggests that language education must be seen as a part of larger social and political views on language use and attitudes. One cannot examine language-in-education policy and planning without examining language policy and planning in their larger political, social and economic contexts. To contextualise the changes in national policies for FLPS in the PRC, this paper begins with a brief introduction to the socio-political context in foreign language education policy and planning in the PRC since its establishment in 1949. The primary motives for these changes, which have led to policy shifts in language choice, curriculum design and material development in FLPS, are also explored and discussed.

\section{Foreign Language Education in the PRC}

Foreign language education has fluctuated since the establishment of the PRC in 1949 as the general line of the Chinese Communist Party (CCP) has changed. Based on an examination of some of the important documentation descriptive of a language planning and policy perspective, and by reviewing related literature, four different phases can be distinguished, each of which demarcates shifts in national policies for FLPS in the PRC: pre-Cultural Revolution (CR) fluctuation; CR disruption; post-CR reform; and from 1994 onwards, popularisation. A brief description of each phase is provided in the following sections to provide a better understanding of recent developments in FLPS in the PRC.

\section{Pre-cultural revolution fluctuation}

During the first few years after its establishment in 1949, the PRC needed assistance from the Soviet Union not only for its economic restoration after World War II and the Civil War (1945-1949) but also for 'protection to forestall Western intervention' (Hsü, 2000: 661). The 'lean to one side' political policy, which meant to lean either to the side of imperialism or to the side of socialism, was adopted by the government, and initially meant creating a concurrent copy of everything from the Soviet Union. This led to a shift in educational policy, resulting in a boom in Russian language teaching and learning in China as the foremost foreign language, but with a resultant neglect of other foreign languages in schools. The problematic imbalance in foreign language education development was soon realised by the government, but the direct impetus for the Chinese government to change its foreign language education policy was the split in Sino-Soviet relations in late 1950s and the improved relationship between China and the West.

Because of the 'inherently political nature' of language policy and planning (Grabe, 1994: viii), the underlying motivation of language policy in reality is almost invariably political rather than linguistic (Baldauf \& Kaplan, 2003: 20). 
When the deterioration of the Sino-Soviet relationship started at the end of the 1950s and then developed into border conflicts in the late 1960s, China began to turn to the United States for support, since it might be able to play an important role in helping to prevent a possible Soviet attack on China. In addition, China was then looking to gain support for its international position (Hsü, 2000). In October 1964, the Seven-Year Program for foreign language education was formulated under the leadership of the MOE and some related departments of the Central Committee, setting up relatively long-term policies for developing foreign language education and for confirming English as the first foreign language in school education in China (Fu, 1986; SFLI, 1993). The Sino-US relationship improved with President Nixon's visit to China in July 1971, and English became increasingly important except during the first few years of the CR.

\section{Cultural revolution disruption}

During the CR (1966-1976), schools were closed for a time in 1966-1967, and education in the PRC at all levels was severely damaged. Foreign languages were considered to be useless, and everything and everybody related to 'foreignness' was criticised. Though the English language started to reappear in the school curriculum in the late 1960s, textbook contents were structured around materials containing political and moral messages rather than having a focus on language learning (e.g. Adamson, 2004). The influence of the CR on foreign language education in the PRC was disastrous. Effectively, previous policies were abandoned, and nothing was done to promote the development of foreign language education.

\section{Post-cultural revolution reform}

The death of Mao Zedong and the end of the CR in 1976 marked a turning point in the history of the PRC and for the development of foreign language education as well. The period between 1976 and 1993 saw the reform of foreign language education in the PRC, and FLPS was trialled in some schools, but was limited to major cities with sufficient teachers and resources. The Third Plenum of the Eleventh Central Committee of the CCP in December 1978 is regarded as an important landmark in the political and economic life of the PRC in the post-Mao era. The CCP rejected Mao's 'politics in command' policy for Deng Xiaoping's 'economics to the fore' ideology. Economic reforms were instituted to accelerate agricultural and industrial growth, an open-door policy was adopted to absorb foreign capital, science and technology, and managerial skills, to increase foreign trade and to promote international communication. The Four Modernisations programme - of industry, agriculture, science and technology and national defence - was launched, the goal of which was to turn China into a leading modern country in the world by the year 2000. Education and educational reform were emphasised for national development and modernisation, and as a consequence, the reconstruction of foreign language education resumed. The MOE held an important meeting on foreign language education between 28 August and 10 September 1978, discussing for the first time since the CR an overall plan for foreign language education in China. In the 'Suggestions on Reinforcement of Foreign Language Education' put 
forward at this meeting and issued by the MOE in March 1979, foreign language study was recommended as one of the 'three fundamental subjects' (san zhu ke) alongside Chinese and mathematics in secondary schools, and these were set as compulsory subjects for entrance examinations to tertiary education. English language education was taken to be the main language focus without neglecting the development of other languages such as Japanese, French, German and Russian. It was also suggested that plans should be made for consistent foreign language education from primary and secondary schools to universities (Fu, 1986; SFLI, 1993).

With the launch of the reform of the economic system in October 1984, the economy in the PRC began to develop rapidly and this became the impetus for reforms to the educational system. Deng's 'Three Orientations', ${ }^{1}$ which provided a signal that education should be oriented towards modernisation, towards the world and towards the future, was regarded as the key directive for the future of education. To fit in with economic reforms and to implement the Three Orientations in education for socialist construction, the National Conference on Education was held in May 1985 in Beijing. It discussed the 'Draft Decision on the Reform of the Educational System', and the 'Decision of the CCP Central Committee on the Reform of the Educational System' was passed and issued on 29 May (MOE, 1985). Under the new directions found in this directive, the Nine-Year Compulsory Education Law took effect in July 1986, and improvements in education at all levels in China soon became obvious (see e.g. Henze, 1992). These directions were reinforced in 'Outline of the Reform and Development of China's Education' (CCP Central Committee, 1993) issued by the CCP Central Committee and the State Council in February 1993, which provided an overall educational reform plan for 1993-2000. This created an even more favourable environment for educational reforms in general and for foreign language education reform in particular.

To respond to these educational reforms, foreign language education reform was also needed. For foreign language education in primary and secondary schools, it was suggested that the status of foreign languages be raised, curricula revised, teachers' language proficiency and teaching skills improved, teaching facilities and resources increased, and international interaction supported. English, Russian and Japanese were included in the primary and secondary school curriculum, but in actual practice English was taught most frequently (SFLI, 1993). One of the reasons for this was that English was in practice the second language of the nation's political, academic, industrial and commercial communities, and in other sectors it was supported because of its importance in the entrance examination for higher levels of schooling (Adamson, 1998).

\section{4 onwards popularisation}

The year 1994 marked the end of an era of reform and the beginning of an era of internationalisation and globalisation of the economic, political and educational systems of the PRC. Since then, the developing mechanisms of a market economy, the return of Hong Kong in 1997, the entry into the World Trade Organization in 2001, and the successful bid for the 2008 Olympic Games all provide indicators that China is playing an increasingly important role on the global stage, which in turn drives further reforms in order to allow China to be 
more involved in the world economy. Education is perceived by the CCP to be a top priority in order to develop human resources. The motivations for China's educational policies are now based on mass quality education, which is characterised by the popularisation of nine years of compulsory education and an increase in enrolment numbers in universities. The development of foreign language education is further emphasised for its role in internationalisation and globalisation, and English language education in particular has gradually been popularised across the entire nation. A new round of reform in the basic education course was launched by the MOE in 1999 and began to be implemented in 2001 under the guidance of the MOE document, 'Program for Course Reform of Basic Education (Trial)' (MOE, 2001c). In response to these basic educational reforms, measures were also taken to improve English language teaching in China, including the design and implementation of a new national English curriculum for primary and secondary schools.

From this review, it is evident that the socio-political situation has had a great impact on the main changes in foreign language educational policies that have occurred in the PRC. The 'education must serve the socialist construction' policy led to shifts in the status of foreign languages in the PRC which in turn resulted in changes to foreign language policy making and its implementation. Ross (1992) indicates that foreign language education in China can be viewed as a barometer of its modernisation trends: registering high when open participation in the global community is perceived to be commensurate with political and economic interests, and low when foreign influence is viewed as threatening to political stability and cultural integrity. As this brief overview suggests, the divergent interpretations of economic development and volatile participation within the international community have created a 'pattern of discontinuous foreign language education' in China (Ross, 1992: 242). In addition, this review indicates that foreign language education has had as its main focus secondary and tertiary study, with FLPS being restricted to a few of the larger cities.

\section{Foreign Language Education Policies for Primary Schools in the PRC}

As the previous section indicates, FLPS programmes in the PRC can be traced back to the 1960s but were not well-planned until recently, as policies were based on political, economic and educational issues rather than being made on linguistic grounds. To gain a better understanding of how these developments in FLPS occurred during the aforementioned four phases in the PRC, three crucial language-in-education issues are now examined: language availability and choice, curriculum design, and materials development.

\section{Language availability and choice}

The selection of foreign languages for primary schools has been influenced by the changing educational policies in the unstable socio-political situations in the PRC. Ager (2001) argues that language policy represents the exercise of political power. This is evident particularly during the earlier years of foreign language-in-education policy and planning in the PRC.

Before the CR, either Russian or English was the foreign language taught in schools following Premier Zhou Enlai's instruction which addressed the 
importance of starting foreign language learning at an early age (Fu, 1986). In 1960, two foreign language schools were established in Beijing, offering foreign language classes at Primary 1. In the same year, foreign languages began to be taught in a few schools at Primary 1 or Primary 2 in Beijing and Shanghai, such as Jingshan School and Fengsheng School in Beijing, and an affiliated Primary School of East China Normal University (Shanghai) (SFLI, 1993). On 30 July 1962, the MOE issued 'Suggestions on Foreign Language Classes in Primary Schools' (SFLI, 1993: 76), proposing that three class hours per week be allocated for the students in their last two years of primary school study, and that the foreign language to be taught should be the one that the students might learn after they entered secondary schools. More opportunities for primary students to learn foreign languages were created by the 'Notice on Setting up Foreign Language Schools' issued by the MOE in July 1963 after approval by the Chinese government (Fu, 1986; SFLI, 1993). This was based on comments by Premier Zhou that foreign languages taught in primary and secondary schools should be organised consistently. More foreign language schools were established in some other cities such as Guangzhou, Chongqing, $\mathrm{Xi}^{\prime}$ an, Changchun and Tianjin where foreign languages were offered from Primary 3. However, the beginning of the CR in 1966 caused the stagnation of foreign language teaching and learning.

The post-CR era saw experiments in FLPS in some major cities in the PRC after the Eleventh National Congress of the CCP in August 1977 when the reconstruction of foreign language education resumed. The 'Suggestions on Reinforcement of Foreign language Education', issued by the MOE in March 1979 (Fu, 1986; SFLI, 1993), which placed foremost importance on foreign language education in primary and secondary schools, indicated that foreign language classes should be offered gradually at Primary 3 in those primary schools in developed and developing cities with sufficient teaching resources. As for the choice of foreign languages, English should be the most important, while other languages such as Japanese, French, German and Russian should not be neglected. It was suggested that education departments at the local level should make their own plans, choosing foreign languages to create a pattern of consistent foreign language education from primary and secondary schools to universities (Fu, 1986; SFLI, 1993). Subsequently, FLPS became widespread in major cities like Beijing, Shanghai and Guangzhou, and more recently in some coastal cities and other developed cities, with English being the dominating foreign language.

With the new round of reform in basic education in 1999, and encouraged by the success of English education in primary schools in Shanghai (Hu, 2002), in January 2001 the MOE issued the 'Guidelines for Promoting English Language Instruction in Primary schools' (MOE, 2001a). This indicated that English would be offered nation-wide to Primary 3 students, starting in cities and suburban areas in autumn 2001 and in rural areas in autumn 2002. While this was a policy document for promoting English teaching and learning in primary schools, it also suggested that Japanese, Russian and other foreign languages should be encouraged in some schools. This policy was further affirmed in the 'Experimental Plan for Curriculum Reform for Compulsory Education' issued by the MOE in November 2001 (MOE, 2001e). 


\section{Curriculum design}

The introduction of FLPS has created the need for curriculum design and development work. However, foreign language curricula for primary schools were not designed in the normal manner when FLPS in the PRC started in early 1960s. In the 1962 'Suggestions on Foreign Language Classes in Primary Schools' (SFLI, 1993), only the basic requirements about what teachers could teach what students for how many hours per week were briefly described (SFLI, 1993: 76), but no formal curriculum was actually designed. When in July 1963 the MOE issued a notice requiring that the 'Twelve-year System School Curriculum (Draft)' be carried out (SFLI, 1993), both English and Russian curricula for secondary schools were then designed, but again no reference was made to foreign language curricula for primary schools.

After the CR, related curricula were immediately developed for the resumption of foreign languages in Chinese primary and secondary schools. In January 1978, the first unified 'Ten-year System School English Curriculum' and 'Tenyear System School Russian Curriculum' were issued by the MOE (Fu, 1986; Zhou, 1995), with general requirements being provided for the skills of listening, speaking, reading, writing, and translating. It was also required that English and Russian instruction be started from Primary 3. The curricula remained in force until the appearance of the English and Russian curricula in 1982 for six-year system secondary school students. Several further adjustments were then made to the national English language curricula for secondary schools during the period 1983-1999, reflecting the increasing status being given to English in Chinese schooling (see e.g. Adamson, 2004). However, a unified national curriculum for English, or for any of the other foreign languages taught in primary schools, was not developed. This might be explained by two facts. Firstly, foreign languages were no longer a compulsory subject in the 1984 national primary school curriculum; English was only offered in primary schools in cities and urban areas with qualified teachers and for programmes consistent with those in secondary schools (Hu, 2005). Secondly, by the mid-1980s, decentralised decision making began to be practised as part of educational reforms to meet the diversity of regional needs and regional development. The 'Decision of the CCP Central Committee on the Reform of Educational System' (MOE, 1985) made local authorities responsible for developing basic education, allowing considerable regional autonomy in exploring and implementing new approaches to education. Shanghai was among the seven economically developed provinces that were allowed to develop their own curriculum and textbooks as well (see Hu, 2002, for a brief introduction on FLPS in Shanghai).

With the arrival of the 21st century, English has become popular in primary schools nationally though it has not been made a compulsory subject. After the launch of a new round of reform in the basic education course by the MOE in 1999, a new national English language curriculum design project for primary and secondary schools in China was begun in November 1999, suggesting that English should start to be offered from Primary 3. The final outcome of this project was the issue of a new national 'English Curriculum for Compulsory Education and Senior Secondary Education' by the MOE in July 2001 (MOE, 2001d), outlining the graded requirements for students from Primary 3 to Year 
12 in English language knowledge and skills. With regard to FLPS, a specific policy document, 'Guidelines for Promoting English Language Instruction in Primary Schools', was issued in January 2001 (MOE, 2001a) that included the basic requirements to be used when implementing English teaching and learning in primary schools. These guidelines included two sets of graded requirements for students starting in Primary 3: (1) a detailed description of the objectives to be attained; and (2) recommended teaching methodology, teaching materials and criteria for assessment. This was the first time in the history of foreign language education in the PRC that a unified national foreign language curriculum was designed on the same basis as that for other subjects and was suggested for official use nation-wide in primary schools.

\section{Materials development}

To meet these new curricular demands, there has been a need for appropriate study materials. The compilation of teaching materials for foreign languages in primary schools has depended on the changes in language choice and changes in educational systems at different times since the establishment of the PRC. The dominant textbooks have been for English and Russian, depending on the prevailing political climate, and have been mainly published by the People's Education Press (PEP).

Given that foreign language education in primary schools only started in the PRC in the early 1960s on a trial basis in several cities, and that there were no corresponding formal curricula before the Cultural Revolution, unified textbooks were not available during the pre-CR period. One series of textbooks was published between March and May 1960 by the PEP, which commissioned the Foreign Languages Department of Beijing Normal University to write the materials covering primary, junior secondary and senior secondary school curricula over a period of nine years. The content of the textbooks was in accordance with the then current policy of 'education must serve the proletarian politics' and the texts had as their focus political messages and moral values (see e.g. Liu, 2005). However, the books were only used briefly in experimental primary and secondary schools for two years before being abandoned because of changes in the political climate and because the contents were poorly constructed (Adamson, 2004).

The first unified foreign language textbook series for primary schools appeared after the CR. Echoing a theme raised at the Eleventh National Congress of the CCP in August 1977 that school textbooks were urgently needed for the Four Modernisations, and to support curriculum development, the PEP published two series of foreign language textbooks in 1978 for primary school students starting from Primary 3: English (six volumes) and Russian (six volumes). These trial editions began to be used in the autumn of 1978 and were trialled for four years before revised editions - six volumes in English and four volumes in Russian - came out. What featured in the textbooks was the integration of moral education with foreign language learning. While idiomatic aspects of foreign languages were taken into account in selecting and writing the texts to meet the students' needs in language knowledge and skills, importance was also attached to the political correctness of the content of the materials to make it clear to the students that they were learning foreign languages to support the country's modernisation efforts (Fu, 1986). 
The educational reform that started in 1985 allowed the decentralisation of textbook writing, but all textbooks for primary and secondary schools could only be used after being approved by the National Evaluation Committee for Primary and Secondary School Textbooks which was set up in 1986 under the State Education Commission. New series of textbooks were published by the PEP with updated content for primary schools, and textbooks compiled by particular institutions were also used in some areas to meet their different needs (e.g. Zhou, 1995). Shanghai, for example, set up its own Curriculum and Teaching Materials Reform Commission in 1988 and started its curricular reform. Instead of the national unified English textbooks for primary school students, new textbooks were published in Shanghai to support its own English curriculum for compulsory basic education (Zhou, 1995).

In keeping with the new English language curriculum of 2001, new teaching materials have been produced, and more may come out since greater autonomy is now available to regional publishers and schools to produce and select teaching materials. In order to improve the quality of the teaching materials for primary and secondary schools, in 2001 the MOE issued 'Temporary Provisions for the Evaluation and Management of Primary and Secondary School Textbooks' (MOE, 2001b). Qualified institutions or individuals, particularly those in rural areas and minority regions, are encouraged to design and write high-quality materials for primary and secondary schools. The Evaluation Committee for Primary and Secondary School Textbooks at the provincial level organises the experts, researchers and teachers to evaluate the materials produced before they are used in that province. Unified textbooks are approved by this committee. The fundamental principles for approving the materials are, firstly, that they fit in with the national laws and educational policies and embody the Three Orientations; secondly, that they support the curricula; and thirdly, that they meet the students' and societal needs (MOE, 2001b). Currently, the most popular textbook series for primary schools are Standard English by the Foreign Language Teaching and Research Press, and those by PEP such as PEP Primary English and Starting Line. All these textbooks have different editions for students at different levels from Primary 1 to Primary 5/6. In addition, textbooks by other publishers may be selected in various provinces for primary schools in different cities.

\section{The Future of FLPS in the PRC}

As the review of the evidence from the PRC shows, decisions on FLPS have been affected primarily by the socio-political context, rather than having been made on the basis of solid theoretical evidence. Kaplan and Baldauf (2003) suggest a theoretical framework in language-in-education planning for the form of a language learning programme. It includes seven policy goals: access policy, personnel policy, curriculum policy, methods and materials policy, resourcing policy, community policy, and evaluation policy. They state further (Kaplan \& Baldauf, 2005: 1014) that success in meeting these goals 'depends largely on policy decisions related to the teachers, the courses of study, and the materials and the resources to be made available'. In this section, the future of FLPS in the PRC is discussed from the perspective of language-in-education planning in terms of teacher and resource availability, and in terms of programme feasibility. 


\section{Teacher and resource availability}

Nunan (2003) has investigated the impact of English on educational policies and practices in several countries in the Asia-Pacific region. The results of his survey show that the English language proficiency of many teachers in the countries surveyed, including China, is not sufficient to provide learners with the rich input needed for successful foreign language acquisition. 'This finding is alarming in view of the popular and some professional views about the conditions required for successful foreign language instruction in the early years' (Nunan, 2003: 607). Teachers need special training in order to meet the needs of younger learners, but in reality, adequate and appropriate training is found to be a major problem in all countries surveyed in his study. To make the situation even worse in the PRC, the nine years of compulsory education and the policy (MOE, 2001a) on promoting English language instruction in primary schools have created a great shortage of teachers. In relation to personnel policy, this policy document suggested measures to be taken to train English teachers to provide quality teaching in primary schools. While it has been suggested that English teacher training programmes should be increased at all levels in teacher education universities, institutes and schools, this policy document encourages graduates from non-teachers' universities or institutes who have studied English as their major but have not taken teacher training programmes to teach in primary schools. In addition, primary school teachers of other subjects who have some English proficiency can be transferred to English teaching or tutoring posts after finishing some training programmes (MOE, 2001a). Analysis of the document shows that the professional qualities that foreign language teachers need have not been carefully studied and are not well supported theoretically. This may create an even bigger gap between policy making and classroom practices in the future.

In addition to teacher proficiency, having a sufficient number of qualified English teachers is another important factor which may determine whether the English programme is successful in primary schools. As part of a project, the author has done some research in this regard on current English education in primary schools in Shandong province in northern China. While no specific figures can be given for how many primary schools have decided to offer English as one of the school subjects, in some cities in the province investigated, all primary schools in cities and suburban areas and some in rural areas have managed to start English language education following the MOE Guidelines (MOE, 2001a). According to the data from some interviews with English teachers, lack of teachers is the issue the interviewees mentioned most, and the cause of this situation is insufficient financial support. English education-related policies were made by the educational structures, but it is the government that makes decisions on how much would be invested in education. The possibility of there being enough money to properly teach English in primary schools has not been seriously taken into account when policy was made. Consequently, the problem is that increased teacher numbers in schools are inadequate, and neither the schools themselves nor the educational departments have the money to employ more teachers. It is very common in many schools for teachers of other subjects to be transferred to teach English, and for one English teacher to teach several classes or even various classes of 
different grades. In some rural areas, a teacher sometimes has to do 'travel teaching', going to a second school immediately after finishing teaching in a first. Overloaded teachers have no time to study the curriculum, the teaching materials and teaching methodologies; nor do they have time for practical training. Their purpose in teaching practice is to finish the prescribed teaching materials within a limited period of time. Although there are a few primary schools in cities where teachers clearly understand the objectives described in the curriculum and can apply the suggestions to their classroom teaching, most of the schools have found that their teachers just hurry through the textbooks. Teachers suggest that only when this financial problem is solved can possibilities be created to deal with the other difficulties that plague successful foreign language education in primary schools.

\section{Programme feasibility}

In addition to teacher and resource availability, Shu (2004) explores some other issues concerning the feasibility of offering English nation-wide to primary school students in the PRC. He examined over 20 primary schools covering six districts in Shanghai, looking at the English curriculum and materials, teacher supply, teaching methodologies, and the methods of assessing student outcomes. Analyses of data from interviews, questionnaires and classroom observations show that English language education in primary schools in Shanghai is in general not successful. The things that have hindered English teaching and learning in primary schools are existing difficulties arising out of teacher qualifications, allocation of teaching hours, attainment of objectives prescribed in the curriculum, and the selection and application of teaching methods in classroom teaching. Given that Shanghai is one of the most developed cities in China, both economically and educationally, and that it is one of the few cities where FLPS was started and developed early, problems arising from the expansion of English language education in primary schools in this one city may have serious implications for the extent of challenges and difficulties to be faced in offering English to primary school students across the whole nation.

Another issue concerning the feasibility of the programme for primary school students in the PRC is the best starting age for foreign language education. Research on the starting age for foreign language education has shown that it would be effective for children to start a new language at about eight years of age (Li, 2001). However, it is still unclear as to whether early exposure to a new language in the classroom will lead to more effective learning. In fact, there has been some research that has indicated that there are advantages in postponing formal second language teaching in specific contexts ( $\mathrm{Hu}, 2005: 18)$. In places where English is taught and learnt as a foreign language, such as the PRC, early English education is not a sufficient condition, as teacher and resource availability are needed for effective learning to occur (Hu, 2005; Shu, 2004).

Research still needs to be done on whether the introduction of English in primary schools in the PRC is successful in terms of students' learning outcomes. However, evidence in this study has shown that the policy decision was made without the requisite overall planning, taking into consideration the factors in language-in-education planning which make a language programme possible. English in the primary schools is promoted to meet societal needs and for quality 
education, but solid theoretical support is necessary for making education policy decisions on FLPS in the PRC.

\section{Acknowledgements}

I wish to express my gratitude to Associate Professor Richard B. Baldauf, Jr and Dr Pauline Bryant for their most valuable comments on an earlier version of this article, and to the anonymous referees for their very helpful suggestions.

\section{Correspondence}

Any correspondence should be directed to Minglin Li, School of Education, The University of Queensland, Brisbane, QLD 4072, Australia (minglin.li@ hotmail.com).

\section{Note}

1. 'Three Orientations' (sange mianxiang) are the inscriptions by Deng Xiaoping for Jingshan Secondary School in Beijing in October 1983. They mean that education should be oriented towards modernisation, towards the world and towards the future. Although it was inscribed locally, it was regarded as the directive for the future of education, and its connotations were later borrowed to be the guidelines for reform and development in science, technology and some other areas.

\section{References}

Adamson, B. (1998) English in China: The junior secondary school curriculum 1949-94. Unpublished PhD thesis, University of Hong Kong.

Adamson, B. (2004) China's English: A History of English in Chinese Education. Hong Kong: Hong Kong University Press.

Ager, D. (2001) Motivation in Language Planning and Language Policy. Clevedon: Multilingual Matters.

Baldauf Jr, R.B. (1990) Language planning and education. In R.B. Baldauf, Jr and A. Luke (eds) Language Planning and Education in Australasia and the South Pacific (pp. 14-24). Clevedon: Multilingual Matters.

Baldauf Jr, R.B. and Kaplan, R.B. (2003) Language policy decisions and power: Who are the actors? In P. Ryan and R. Terborg (eds) Language: Issues of Inequality. Mexico City: Universidad Nacional Autonoma de Mexico.

CCP Central Committee (1993) Zhongguo jiaoyu gaige he fazhan gangyao [Outline of the Reform and Development of China's Education]. Beijing: CCP Central Committee.

Cooper, R.L. (1989) Language Planning and Social Change. Cambridge: Cambridge University Press.

Fu, K. (1986) Zhongguo Waiyu Jiaoyu Shi [A History of Foreign language Teaching in China]. Shanghai: Shanghai Foreign Language Education Press.

Grabe, W. (1994) Foreword. In W. Grabe (ed.) Annual Review of Applied Linguistics 14 (pp. vii-xii). Cambridge: Cambridge University Press.

Grabe, W. and Kaplan R.B. (1992) Introduction to Applied Linguistics. Reading, MA: Addison-Wesley.

Henze, J. (1992) The formal education system and modernisation: An analysis of developments since 1978. In R. Hayhoe (ed.) Education and Modernization: The Chinese Experience (pp. 103-139). New York: Pergamon Press.

Hsü, I.C.Y. (2000) The Rise of Modern China (6th edn). New York: Oxford University Press.

Hu, G. (2002) Recent important developments in secondary English-language teaching in the People's Republic of China. Language, Culture and Curriculum 15 (1), 30-49. 
Hu, G. (2005) English language education in China: Policies, progress, and problems. Language Policy 4 (1), 5-24.

Ingram, D.E. (1989) Language-in-education planning. In R.B. Kaplan, C.A. Ferguson, H.G. Widdowson, G.R. Tucker, W. Grabe and J. Yalden (eds) Annual Review of Applied Linguistics 10 (pp. 53-78). New York: Cambridge University Press.

Judd, E.L. (1992) Language-in-education policy and planning. In W. Grabe and R.B. Kaplan (eds) Introduction to Applied Linguistics (pp. 169-187). Reading, MA: Addison-Wesley.

Kaplan, R.B. (1990) Introduction: Language planning in theory and practice. In R.B. Baldauf, Jr and A. Luke (eds) Language Planning and Education in Australasia and the South Pacific (pp. 3-13). Clevedon: Multilingual Matters.

Kaplan, R.B. and Baldauf Jr, R.B. (1997) Language Planning: From Practice to Theory. Clevedon: Multilingual Matters.

Kaplan, R.B. and Baldauf Jr, R.B. (2003) Language and Language-in-Education Planning in the Pacific Basin. Dordrecht: Kluwer Academic.

Kaplan, R.B. and Baldauf Jr, R.B. (2005) Language-in-education policy and planning. In E. Hinkel (ed.) Handbook of Research in Second Language Teaching and Learning (pp. 1013-1034). Mahwah, NJ: Erlbaum.

Li, J. (2001) Kaishe yingyu kecheng jiaoyubu xishuo duanxiang [MOE briefing on English language education in primary schools]. Zhongguo jiaoyu bao, 12 March 2001, p. 3.

Liu, Y.B. (2005) The construction of cultural values and beliefs in Chinese language textbooks. Discourse 26 (1), 15-30.

MOE (1985) Zhonggong zhongyang guanyu jiaoyu tizhi gaige de jueding [Decision of the CCP Central Committee on the Reform of the Educational System]. May 1985. Beijing: MOE.

MOE (2001a) Jiaoyubu guanyu jiji tuijin xiaoxue kaishe yingyu kecheng de zhidao yijian [Guidelines for Promoting English Language Instruction in Primary schools]. January 2001. Beijing: MOE.

MOE (2001b) Zhongxiaoxue jiaocai bianxie shending guanli zanxing banfa [Temporary Provisions for the Evaluation and Management of Primary and Secondary School Textbooks]. June 2001. Beijing: MOE.

MOE (2001c) Jichu jiaoyu kecheng gaige gangyao (shixing) [Program for Course Reform of Basic Education (Trial)]. July 2001. Beijing: MOE.

MOE (2001d) Quanrizhi yiwu jiaoyu putong gaoji zhongxue yingyu kecheng biaozhun (shiyangao) [English Curriculum for Compulsory Education and Senior Secondary Education (Trial)]. July 2001. Beijing: MOE.

MOE (2001e) Yizujiaoyu kechengshezhi shiyan fang'an [Experimental Plan for Curriculum Reform for Compulsory Education]. November 2001. Beijing: MOE.

Nunan, D. (2003) The impact of English as a global language on educational policies and practices in the Asia-Pacific region. TESOL Quarterly 37 (4), 589-613.

Ross, H. (1992) Foreign language education as a barometer of modernization. In R. Hayhoe (ed.) Education and Modernization: The Chinese Experience (pp. 239-254). Oxford: Pergamon.

Rubin, J. and Jernudd, B.H. (1971) Introduction: Language planning as an element in modernization. In J. Rubin and B.H. Jernudd (eds) Can Language Be Planned? Sociolinguistic Theory and Practice for Developing Nations (pp. xiii-xxiv). Honolulu: The University Press of Hawaii.

SFLI (Sichuan Foreign Language Institute) (1993) Zhongguo Waiyu Jiaoyu Yaoshi Lu 1949-1989 [Important events in foreign language teaching in China 1949-1989]. Beijing: Foreign Language Teaching and Research Press.

Shu, D. (2004) FLT in China: Problems and Suggested Solutions. Shanghai: Shanghai Foreign Language Education Press.

Spolsky, B. and Shohamy, E. (2000) Language practice, language ideology, and language policy. In R.D. Lambert and E. Shohamy (eds) Language Policy and Pedagogy (pp. 1-41). Philadelphia, PA: John Benjamins.

Zhou, L. (1995) Zhongguo Zhongxue Yingyu Jiaoyu Baike Quanshu [An Encyclopaedia of English Education in Middle Schools in China]. Shenyang: Northeastern University Press. 


\section{The Author}

Minglin Li is currently undertaking a PhD degree at the School of Education, The University of Queensland. She is examining the English (as a foreign language) curriculum changes from the perspective of language and language-ineducation policy and planning in the PRC. Previously, she was a Lecturer and then an Associate Professor in English in the tertiary sector in China. Her research interests are English phonetics, EFL teaching methodology and EFL teacher education. She has published studies in these areas in foreign language teaching and research journals in China, and has contributed several chapters to edited books. 